\title{
Visualization of macroseismic parameters during examination of epicentral zones of strong earthquakes
}

\author{
Lutfulla Khamidov ${ }^{1}$, Soqi Makhkamov ${ }^{2}$, Maxmud Turapov $^{3}$, Safarali Kholmirzaev ${ }^{3}$, \\ Shavkat Suyunov ${ }^{3}$, and Bekzod Kudratov ${ }^{4 *}$ \\ ${ }^{1}$ Institute of Seismology named after G.A. Mavlyanov of the Academy of Sciences of the Republic of \\ Uzbekistan, Tashkent, Uzbekistan \\ ${ }^{2}$ Specialized boarding school named after Abu Ali Ibn Sino, Tashkent, Uzbekistan \\ ${ }^{3}$ Tashkent Institute of Architecture and Civil Engineering, Tashkent, Uzbekistan \\ ${ }^{4}$ Tashkent State Transport University, Tashkent, Uzbekistan
}

\begin{abstract}
The article discusses the fragile destruction of building materials during strong earthquakes, the features of the macroseismic effect of cracking expressed in the protective coatings of buildings; it is recommended to optimize the composition based on polymer by composition that increases the crack resistance of plaster solutions. In particular, the visualization of macroseismic parameters is given on the example of the survey of the epicentral zones of the Tashkent (2008), Cannes (2011) and Marzhanbulak (2013) strong earthquakes that occurred in Kyrgyzstan and Uzbekistan. Possible directions of crack development and density of their distribution over the macroseismic area are analyzed. It was revealed that the vulnerability to micro-destruction of types of protective materials is proportional to the seismic intensity and is mainly due to the intensity of seismic vibrations.
\end{abstract}

\section{Introduction}

The urgency of the problem of long-term development of earthquake-resistant protective coatings, based on macroseismic estimates of real strong earthquakes, required the substantiation of some new scientific provisions. The use of new types of earthquakeresistant protective materials, improving the strength of enclosing structures, lead to a reduction in the cost of repair and restoration work of buildings and an increase in indoor comfort. As the practice of construction works in Uzbekistan over the past 25 years has shown, the use of effective acoustic materials, similar in structure and production methods to earthquake-resistant materials, increases the culture of construction, the comfort of living conditions. The increase in the macroscopic stability of these materials significantly affects the macroseismic parameters when examining the epicentral zones of strong earthquakes. Visualization of the macroseismic parameters of the destruction of protective coatings during the survey outside the epicentral zones of strong earthquakes makes it possible to

\footnotetext{
*Corresponding author: kudratov_bekzod@mail.ru
} 
assess the magnitude of earthquakes on a particular building more adequately, which turned out to be more unpleasant to high-frequency loads. In recent years, several full-scale studies of building vibrations from low-frequency transit and high frequency local earthquakes have been conducted in Uzbekistan and abroad, showing that the deformations of protective coatings along the length of buildings are not the same. In some cases, local deformations in their plane are significant for prefabricated and monolithic structures.

We have studied the effect on the macroseismic parameters of visually detected parameters of the fracture density of protective coatings in the zones of moderate fluctuations of several strong earthquakes that occurred in the recent past in Kyrgyzstan and Uzbekistan.

\section{Methods}

Tashkent August 22, 2008 earthquake the hypocenter of this earthquake was under the central part of the city of Tashkent. According to the data of the seismic station "Tashkent" in the city of Tashkent, on August 22, 2008, there was an earthquake of magnitude $M=4.7$, intensity $\mathrm{J}=6-7$ points at a depth of $\mathrm{h} \sim 10 \mathrm{~km}$. Macroseismic surveys immediately after the earthquake were carried out by a group of scientists from the Institute of Seismology of the Academy of Sciences of the Republic of Uzbekistan (IS AS RUz) [1]. Two epicentral groups were organized, which, 40 minutes after the earthquake, left for the supposed area of the earthquake epicentre and conducted surveys in different sectors of the city. The epicentral groups surveyed the Shaykhantokhur and Almazar districts (central and old-city parts), starting from the historical complex "Khazrat Imam" in the east southeast to the city centre. Buildings, structures were examined and residents of St. Abu Bakr Shoshiy (possible pleistoseist zone), 1, 2 dead ends, houses No. 31,28, 23, 43, 32, 51, 53, 74 [1]. Along Sag ban Street to the west of the starting point (IT), dead end 2, houses \# 213, 207, $84,212,118,223$ and others were surveyed immediately after the earthquake. The area of the Eski-Juva bazaar (south of IT), the Jar sports complex, as well as the Chor-Su square, the Kukaltash madrasah, Khoja Akhror (south-west of IT), the area of the shopping arcade of the Malika complex east of IT and other parts of the city Tashkent were surveyed in detail over the next three days after the seismic event. Seismogenic cracks of various ranks were found in many houses: shallow, deep, though. Everywhere there is a scree of plaster, there are cases of falling out of a large array of clay plaster, cases of chimneys on roofs collapsing. Most of the above houses were built after the famous Tashkent earthquake on April 26, 1966 [1].

Cannes July 11, 2011 earthquake. After conducting an epicentral visual macroseismic survey, the consequences of the Cannes earthquake on July 11, 2011, in the southern part of the Fergana Valley, which swept the territory of Kyrgyzstan and Uzbekistan, were examined [2]. According to these data, the epicentre of the earthquake is located on the territory of Kyrgyzstan, $10 \mathrm{~km}$ southeast of the village of Kann. This earthquake was strongly manifested in the southwestern part of the Fergana Valley, especially in structures in the settlements of Rishtan, Kaptut, Oltiarik, Chimyon, Vuadil, Sokh and others Damage to buildings, cracking in plastering materials used by old and modern methods. On the macroseismic map, zones with 8,7 and 6 points seismic intensity. On the map, the isoseismic zone of 8 point intensity (epicentral zone) is located on the territory of Kyrgyzstan, where we did not conduct macroseismic studies. Macroseismic survey of the village Cannes was conducted by the staff of the Institute of Seismology of the National Academy of Sciences of Kyrgyzstan (Kamchibekov Muratali and others) [2]. According to eyewitnesses, the earthquake was preceded and accompanied by a strong underground rumble of an explosive nature in the epicentral zone and the adjacent territory. According to the materials of the survey of the consequences of the earthquake on the territory of 
Uzbekistan, the maximum intensity reached 7-8 points in the villages of Langar, Rishton and sokh. The seismic intensity of 7 on the MSK-64 scale (the scale of the Institute of Physicists of the Earth of the Russian Academy of Sciences) [3] manifested itself in the settlements: Langar, Kaptut, Buadil, Rishton and Sokh. Kishlak Langar is located $0.5 \mathrm{~km}$ east of the sanatorium of railway workers of Uzbekistan "Chimion". Here the intensity of the earthquake is estimated at 7-8 points. At the same time, in individual residential houses with a partial wooden frame (with filling between the frame space from "guvalyak"), there were cracks in the adobe plaster along with the frames, collapse between the frame filling, parts of the wall collapse, sometimes a complete collapse of the house. However, we were interested in more than 7 and 6 point zones, where the influence of high-frequency vibrations on the state of protective coatings is significant.

Marzhanbulak earthquake on May 26, 2013. According to the seismic station "Tashkent" in the Jizzakh region and the city of Tashkent on May 26, 2013 at 11:16 am, by Tashkent time, an earthquake with a magnitude $M=6.2$, and an intensity $\mathrm{J}=6-7$ points occurred with a hypocenter at a depth of $\mathrm{h} \sim 15 \mathrm{~km}$. The epicentre of this earthquake was in the mountainous area of Gubdutau in the city. A preliminary survey of buildings in a possible pleistoseist zone immediately after the earthquake was carried out by the authors of this work 2 hours after the main shock. The photographs show the most serious injuries in the examined areas of the epicentral zone "Fig.1-a, b".

In D.Navruz, minor destruction of ceilings was observed. According to data from $\mathrm{s} / \mathrm{s}$ Tashkent, preliminary coordinates were $40^{\circ} 02$ and $67^{\circ} 00$. GPS determined the direction of the epicentre of the vero-west at an angle of $30^{\circ}$, determining the azimuth; it was estimated that the instrumental epicentre is about $37 \mathrm{~km}$. It was decided to start the survey of buildings from the northwest in the direction of the village Chelek. On the way to the village, Dakhbed houses and schools were observed in which small cracks were observed in the corner zones of the load-bearing and in the intervals of windows up to $40-70 \mathrm{~cm}$, the distribution density of cracks in the walls towards the epicentre was $\rho_{\mathrm{mp}}=0.5$. All buildings are private adobe and partly brick buildings. Rarely come across buildings (school, college, etc. administrative) of liquefied brick. Building finishing mortars are mainly adobe with adobe, clay with sand and alabaster coating with $50-50 \%$ sand.

In two brick buildings of D. Dehbed (including a school), no significant damage was noticed (the density of cracks is below $\rho_{\mathrm{mp}}=0.3$. Macroseismic assessment force is about $\mathrm{J}$ 5 points. The next was two villages in which a similar condition was observed. Il-Nazar, several buildings were noticed, in which at the junction of the ceilings there are cracks in the direction of the epicentre $(\rho \mathrm{mp}=0.5)$. In the college of Il-Nazar, there are cracks longer $(70-80 \mathrm{~cm})$, also indicating the direction of the epicentre a little lower To the east In the area of Akkurgan village to Chandir village the same picture $(\mathrm{J}=5-6$ points) In the area of $\mathrm{P}$. Yangiravat the number of cracks in buildings began to grow ( $\rho m p=0.6 ; \mathrm{J}=5-6$ points). In the village of Chelek, the same state of affairs is 5-6 points. Dale towards D. Karakissarak (12 km to the preliminary instrumental epicentre), there are breaks and falling mortars of the finishing coating of buildings, plaster both from the walls and from the ceilings $\left(\rho_{\mathrm{mp}}=0.8 ; \mathrm{J}=6\right.$ points). All buildings of private houses D.Chalmuin and D.Karakissarak are adobe, low ceilings, shepherds' dwellings and other buildings of poor quality and stability. There are through cracks indicating the direction of the epicentre (east) 5-6 points. Further, the survey continued in the direction of the village of Dzhuma, the near zone of the Batil Khuzhalik site and the instrumental epicentre (about $8 \mathrm{~km}$ ). 


\section{Results and Discussion}

The constructions of houses in Tashkent by 2008 in all the studied zones are different. Still, most of them were built from local materials using the traditional construction of the guval, pakhs, using adobe bricks. The 2008 Tashkent earthquake occurred 42 years after the famous Tashkent earthquake of 1966. A feature of these earthquakes is that the hypocenter of the focus is located directly under the central part of the city, which has more than a million inhabitants.

It is known that the possibility of cracking in building materials according to [3-5] is expressed from the conditions of maximum loads:

$$
s=\frac{R_{c k} F}{\mu} ; R_{c k}=\sqrt{R_{g l}\left(R_{g l}+\sigma_{0}\right)}
$$

where: $\mathrm{S}$ is the horizontal seismic shear force; $\mathrm{F}$ is the area of the horizontal section of the wall; $\mu$ is the coefficient of the shape, equal according to [4] to 1.5 for a rectangular section. In [4], a wall is considered to not carry vertical loads, except for its own weight, with a height of $3 \mathrm{~m}$, which corresponds to the height of one floor. Then at half the height of the wall $\sigma_{o}=1.5-1.7=2.55 \mathrm{~m} / \mathrm{m}^{2}$.

As indicated in [4] for the masonry of the 3rd category Rgl-4t / m; made in the same place, a stronger assumption, assuming that Yagya corresponds to a solution of grade 2 and is equal to $1 \mathrm{t} / \mathrm{m} 2(0.1 \mathrm{~kg} / \mathrm{cm} 2)$. Then the condition for the formation of an oblique crack will be:

$$
R_{C k}=\sqrt{1(1+2.55}=1.88 \mathrm{~m} / \mathrm{m}^{2}, S>\frac{1,88}{1,5}=1.26 \mathrm{~m} / \mathrm{m}^{2}
$$

On the other hand, taking the seismic load for the upper floors equal to $\mathrm{s}=3.8 \mathrm{k} \_\mathrm{c} \mathrm{Q}$, it is determined that for the formation of an oblique crack in the wall, there must be

$$
k_{C}>\frac{1.26}{3.8 Q}=\frac{0.332}{Q}
$$

Where: $Q$ is the weight of the structure that transfers the horizontal load to the given wall.

If we assume, as indicated in [4], that the distance between the transverse walls is twice the length of the transverse wall, then, taking into account the weight of the floor, we can assume $Q=4 N$, where $N$ is the vertical load at half the height of the wall. For an end wall similar to that shown in Fig. 19, the condition for the occurrence of an oblique crack will be:

$$
k_{C}>\frac{0.332}{4 \cdot 2.55}=0.32
$$

According to the estimates of Kh.S. Sagdiev et al. [6], based on the measurement results, frequency spectra, the prevailing periods and amplitudes of longitudinal, transverse and vertical displacements and vibration accelerations of the subgrade, basement, first and middle floors, as well as the attic of the building, were determined.

From the obtained measurement data of the maximum values of the acceleration of ground vibration, the first floor and the attic of the building of the Institute of Mechanics and Seismic Resistance of Structures of the Academy of Sciences of the Republic of Uzbekistan during an earthquake in three mutually perpendicular directions are shown, respectively, in Table. 1. It was revealed that the intensity of the earthquake impact on the 
maximum values of the horizontal acceleration of ground vibration is about 6 points and on the vertical component about 7 points.

Table 1.

The maximum values of the ground vibration acceleration, the first floor and the attic of the IMSS building of the Academy of Sciences of Uzbekistan during the Tashkent earthquake on August 22, 2008, in three mutually perpendicular directions [6].

\begin{tabular}{|c|c|c|c|}
\hline score & priming & 1 st floor & attic \\
\hline$>6$ & $u_{0 y}=73.2 \mathrm{cM} / \mathrm{c}^{2}$ & $u_{0 y}-94.4 \mathrm{cM} / \mathrm{c}^{2}$ & $u_{0 y}=123.1 \mathrm{~cm} / \mathrm{c}^{2}$ \\
\hline$\approx 6$ & $u_{0 y}=56.6 \mathrm{cM} / \mathrm{c}^{2}$ & $u_{0 y}-63.6 \mathrm{cM} / \mathrm{c}^{2}$ & $u_{0 y}=138.5 \mathrm{~cm} / \mathrm{c}^{2}$ \\
\hline$\approx 7$ & $u_{0 y}=113.3 \mathrm{cM} / \mathrm{c}^{2}$ & $u_{0 y}=117.7 \mathrm{cM} / \mathrm{c}^{2}$ & $u_{0 y}=197.9 \mathrm{~cm} / \mathrm{c}^{2}$ \\
\hline
\end{tabular}

The vibration acceleration of the ground floor and the ground almost coincide, and the attic of the building is 1.5-2 times greater than the vibration acceleration of the building foundation [6]. Plasters in new buildings in the surveyed districts of Tashkent and the Fergana Valley are subdivided into plasters that meet the usual requirements; plasters with additional properties and plasters with special properties. It is known that the group of plasters with additional properties, as a rule, includes water-retaining plasters, hydrophobic plasters, plasters for external work with increased strength, plasters for internal work with increased abrasion resistance, wall and ceiling plasters for internal work in rooms with high humidity normative assessments are shown in $[7,8,9]$.

Table 2. The density of cracks on the duration of the oscillation in the buildings of the city of Tashkent (according to data from [1])

\begin{tabular}{|c|c|c|c|c|c|c|c|}
\hline \multirow{2}{*}{ № } & \multirow{2}{*}{$\begin{array}{c}\text { Structural element } \\
\text { type. }\end{array}$} & \multicolumn{6}{|c|}{$\begin{array}{c}\text { The number of cracks per } \mathrm{m}^{2} \text { under seismic loads in J }=7 \text { and 6 point } \\
\text { zones during the Tashkent earthquake on August 22, 2008 (M 4.7) }\end{array}$} \\
\cline { 3 - 8 } & $\begin{array}{c}\text { Malika 1 } \\
\mathrm{km}\end{array}$ & $\begin{array}{c}\text { Xast Imam } \\
2 \mathrm{~km}\end{array}$ & $\begin{array}{c}\text { Sagban } \\
3 \mathrm{~km}\end{array}$ & $\begin{array}{c}\text { Chorsu 4 } \\
\mathrm{km}\end{array}$ & $\begin{array}{c}\text { Qoraqamish } \\
5 \mathrm{~km}\end{array}$ & $\begin{array}{c}\text { Risovay } \\
\mathrm{a} \\
6 \mathrm{~km}\end{array}$ \\
\hline 1 & plaster & 2.4 & 2.2 & 1.6 & 0.7 & 1.5 & 1.1 \\
\hline 2 & $\begin{array}{c}\text { Gypsum coating with } \\
\text { sand 50-50\% }\end{array}$ & 0.08 & 0.06 & 0.03 & 0.02 & 0.06 & 0.015 \\
\hline 3 & $\begin{array}{c}\text { Cement-gypsum } \\
\text { coating 50 to 50\% }\end{array}$ & 0.04 & 0.03 & 0.02 & 0.018 & 0.01 & 0.008 \\
\hline 4 & $\begin{array}{c}\text { Clay cover with cut } \\
\text { straw 50 per }\end{array}$ & 4.3 & 4.0 & 3.3 & 2.7 & 2.1 & and \\
\hline 5 & Composite tiles & 0.03 & 0.02 & 0.01 & 0.01 & 0.01 & 0.001 \\
\hline
\end{tabular}

The buildings surveyed in the Fergana Valley during the 2011 Cannes earthquake in the areas of Oltiarik, Rishton and Chimen, which received numerous oblique cracks in the upper floors, especially of colleges, as well as one-story buildings, showed that the adhesion strength of a brick with a protective coating is in most cases lower than its stiffness. But at the same time, in the districts of Tashkent city in 2008, Vuadil, Fergana and Shakhimardan in 2011 and Marzhanbulak, Gallaaral in the 6-7 point shock zone, there are many buildings where cracks appeared under the condition $\mathrm{kc}>0.05$.

As can be seen from the surveys, elements of protective coatings during earthquakes can operate in the area of nonlinear deformations. Under these conditions, a significant role for assessing the damageability of protective coatings, along with the level of seismic loads, is played by the duration of the active phase of oscillations from earthquakes $\Delta t$, characterized by sufficiently high accelerations and total loads for a long time from local and transit earthquakes characterized by low values of accelerations. 
The tragic consequences of the Cannes earthquake are mainly associated with the collapse of the aivans attached to residential buildings. Here, the outer end of the beam rests on the transverse beams on the racks, and the other end of the aivan beam rests on the niche of the house beam sealed above. Often, to give a slope (overlapping the aivan), a 20-30 cm long piece is inserted between the beams of the house and the aivan. This creates an extra hinge that weakens the already weak design of the iwan. The structures of ayvans will not collapse under static (i.e., without seismic impact), and under dynamics - (i.e., under the seismic impact of 6 and higher points) - they may collapse. The authors previously observed such a case during the survey of the Chimion earthquake of 06.05.1982. $(\mathrm{M}=5.7$; $\mathrm{H}=18 \mathrm{~km} ; 10=7-8$ points; epicentral distance $-24 \mathrm{~km}$ ) in the Khurramabad village.

With repeated loading, the comfort conditions in all rooms of living quarters and offices begin to decrease seriously, which leads to unforeseen costs for the renovation of plaster materials in general. Table 3 shows our preliminary determinations of the density of distribution of cracks from the duration of oscillations in the buildings of southern Fergana. We made a visual and analytical survey on July 21, 2011, February 2012 and May 2012.

Table 3. Density of cracks on the duration of fluctuations in buildings in southern Fergana

\begin{tabular}{|c|c|c|c|c|c|c|c|}
\hline \multirow[t]{2}{*}{ № } & \multirow{2}{*}{$\begin{array}{l}\text { Type of structural } \\
\text { element (The total } \\
\text { duration of vibrations } \\
\text { from all aftershocks + } \\
\text { transit earthquakes } \\
\sum \Delta \mathrm{t} \text { i } \approx 1830 \mathrm{sec} \text { ). }\end{array}$} & \multicolumn{6}{|c|}{$\begin{array}{l}\text { The number of cracks per } \mathrm{m}^{2} \text { under seismic loads in } J=7,6,5 \\
\text { and } 4 \text { points in the Cannes earthquake on July } 11,2011 .\end{array}$} \\
\hline & & $\begin{array}{l}\text { Chimyo } \\
\text { n } 25 \mathrm{~km} \text {. }\end{array}$ & $\begin{array}{c}\text { Lyanga } \\
\text { r } \\
20 \mathrm{~km}\end{array}$ & $\begin{array}{r}\text { Vadil } \\
40 \mathrm{~km} .\end{array}$ & $\begin{array}{l}\text { Bagdat } \\
40 \mathrm{~km} .\end{array}$ & $\begin{array}{c}\text { Rishta } \\
\text { n } \\
30 \\
\mathrm{~km} .\end{array}$ & $\begin{array}{c}\text { Fergana } \\
60 \mathrm{~km}\end{array}$ \\
\hline 1 & Water-retaining plasters & 1.3 & 1.5 & 0.8 & 1 & 1 & 0.5 \\
\hline 2 & $\begin{array}{l}\text { High durability external } \\
\text { plasters. }\end{array}$ & 0.6 & 0.6 & 0.4 & 0.5 & 0.5 & 0.3 \\
\hline 3 & $\begin{array}{l}\text { Wall and ceiling } \\
\text { plasters for interior use. }\end{array}$ & 0.8 & 0.8 & 0.4 & 0.6 & 0.6 & 0.3 \\
\hline 4 & Plaster & 2.0 & 2.5 & 1.5 & 1.7 & 2.0 & 0.8 \\
\hline 5 & $\begin{array}{l}\text { Gypsum coating with } \\
\text { sand } 50-50 \% \text {. }\end{array}$ & 0.2 & 0.2 & 0.03 & 0.05 & 0.05 & 0.01 \\
\hline 6 & $\begin{array}{l}\text { Cement-gypsum } \\
\text { coating } 50 \text { to } 50 \%\end{array}$ & 0.06 & 0.06 & 0.03 & 0.04 & 0.04 & 0.02 \\
\hline 7 & $\begin{array}{l}\text { Clay cover with cut } \\
\text { straw } 50 \text { per }\end{array}$ & 5.3 & 6 & 3.2 & 4.5 & 5.0 & 1.5 \\
\hline 8 & Composite tiles & 0.03 & 0.05 & 0.02 & 0.04 & 0.04 & 0.01 \\
\hline
\end{tabular}

The seismic impact during the Cannes earthquake on the above-described settlements was about 7 points. Therefore, more cases of ayvan collapse were observed. On the isoseismal map of this earthquake, the city of Tashkent is located in a 4-point zone. The intensity of tremors in Tashkent and many other earthquakes in the Fergana depression was felt higher than the initial magnitude of the territory by $0.5-1.0$ points.

In the area of the Marzhanbulak earthquake in 2013 in the village of Dzhanbay at the time of the earthquake in the buildings of shops and car service centres, as well as in several private houses, cracks were noticed in the ceiling zones and window openings with sizes of about $30-50 \mathrm{~cm}$, the distribution density of cracks (the average number of cracks Tri per square meter of wall area $\mathrm{Si}$, divided by the average wall thickness $\Delta \mathrm{h}$, and $\mathrm{\rho mp}=$ $\mathrm{Tg} / / \mathrm{Si} \Delta \mathrm{hi}$ ) in building finishing mortars $\rho \mathrm{mp}=0.3$. In Dzhuma village, there is practically no serious damage visible from the outside. Inside the college, there are crossshaped cracks in the east direction (5-6 points). Further, in the village "Balik Khuzhalik" a strong roar was heard before the earthquake, and people working in the meadow (5-6 people were building the foundation of one house) saw a wave going from the northeast side. There, more than 50 hectares of sown barley and on an even rise (slope of about 6 
degrees), a green field is visible. Also, the impact was mainly from the bottom and fluctuated for about 10 seconds. Through cracks and displacement of a corner, joints were noticed in five buildings of the settlement. Liquefied brick buildings have cracks in both door and window openings ( $\rho \mathrm{mp}=0.8 ; \mathrm{J}=6$ points). It also has a fall of various types of plastering materials (clay, cement, etc.). The survey was further carried out up to the north along the adir zone about $17 \mathrm{~km}$. In the settlements of shepherds (Karatash, Beshkal, Osarchorsha, etc.) on the top of the adyrs, no severe damage was noticed. We went down from the adyrs in the area of Anoy (closer to Aktash). There, too, the same state of affairs ( 5 points). Then we drove in a southeastern direction towards the village of Marzhanbulak. As we approached Marzhanbulak with Annoy, an increase in fracturing was observed in buildings (Kamar, Aktash and others ( $\rho m p=1.2 ; \mathrm{J}=6$ points)). In the settlement of Marzhanbulak, in administrative buildings, falls of brickwork in a warehouse (height above sea level $874 \mathrm{~m}$ ) were determined. With the permission of the building administration, the 3-storey building, separate dining room and auxiliary buildings were examined. Everywhere the same picture is continuous falling of plasters from all walls, destruction of window openings, cross-shaped through cracks in an azimuthal direction pointing to the epicentre ( $\rho m p=2.5 ; \mathrm{J}=6-7$ points). In the dining room, $50 \%$ of the plaster fell. There is a partial destruction of the joints of the bearing walls. In the main shop, there are glass fragments from all windows; on the ridge part of the building, there is a slab waste by $8-10$ $\mathrm{cm}$. Inside there are solid drops of plasters. No concrete destruction of buildings or walls was noticed.

Further to the northwest of the plant, a two-storey, brick school building was examined in several villages in Gobdun, almost $60 \%$ of both cement mortar and alabaster plasters fell. There are through cruciform cracks ( $\rho \mathrm{mp}=2.8 ; \mathrm{J}=7$ points).

Table 4. We showed our preliminary determinations of the density of distribution of cracks from the duration of oscillations in the buildings of the Gallaral region of the Jizzakh region, in which we did visual analytical surveys for May 26-27, 2013

\begin{tabular}{|c|c|c|c|c|c|c|c|}
\hline \multirow{2}{*}{ № } & \multirow{2}{*}{$\begin{array}{c}\text { Structural } \\
\text { element type. }\end{array}$} & \multicolumn{6}{|c|}{$\begin{array}{c}\text { The number of cracks per } \mathrm{m}^{2} \text { at seismic loads in } \mathrm{J}=7 \text { and 6 points in the } \\
\text { Marzhanbulak earthquake on May 26, 2013 (M=6.2). }\end{array}$} \\
\cline { 3 - 8 } & $\begin{array}{c}\text { Chelak } \\
22 \mathrm{~km} .\end{array}$ & $\begin{array}{c}\text { Juma } \\
17 \mathrm{~km}\end{array}$ & $\begin{array}{c}\text { Aktash } \\
12 \mathrm{~km} .\end{array}$ & $\begin{array}{c}\text { Xanaka 8 } \\
\mathrm{km}\end{array}$ & $\begin{array}{c}\text { Marjonbulak } \\
5 \mathrm{~km}\end{array}$ & $\begin{array}{c}\text { Gobdun } \\
2 \mathrm{~km} .\end{array}$ \\
\hline 1 & plaster & 1.2 & 2.5 & 1.5 & 0.8 & 1.7 & 2.0 \\
\hline 2 & Gypsum coating & 0.5 & 0.2 & 0.03 & 0.01 & 0.05 & 0.05 \\
\hline 3 & Cement-gypsum & 0.6 & 0.06 & 0.03 & 0.02 & 0.04 & 0.04 \\
\hline 4 & Clay cover with & 1.3 & 6 & 3.2 & 1.5 & 4.5 & 5.0 \\
\hline 5 & Composite tiles & 0.02 & 0.05 & 0.02 & 0.01 & 0.04 & 0.04 \\
\hline
\end{tabular}

In subsequent years after the Marzhanbulak earthquake on May 26, 2013, with a magnitude of $\mathrm{M}=6.2$, there were no strong earthquakes in Uzbekistan. During the 2016 Kibat earthquake with a magnitude of $\mathrm{M}=5.0$ and the Bakhmal earthquake on September 29 with a magnitude of $\mathrm{M}=5.1$, there was no dense arrangement of buildings and structures in the near zone of the epicentre of these earthquakes (at a distance of 2 to $4 \mathrm{~km}$ in the main building of schools and lyceums) practically did not change the value of the macroseismic parameters of the densities and degrees of fractures set forth in Tables 3 and 4.

They showed that private construction is the main source of fracture density. They do not fully take into account the Building Code for seismically active zones of Uzbekistan.

To increase the crack resistance of finishing, plaster solutions, research and experimental studies were carried out using polymer compositions to optimize 
compositions at the Tashkent Architectural and Construction Institute, together with the Institute of Seismology of the Academy of Sciences of the Republic of Uzbekistan. The results of the research revealed (Tables $5,6,7,8)$ that the introduction of the gel polymer GP-1 $(0.2-0.3 \%)$ and the superplasticizer J-1 (0.2-0.3\%) into the solutions, the waterretaining ability, the property of delamination decreases while increasing the density of the solution, which affects the increase in crack resistance, improvement of the physical, mechanical and operational properties of finishing composite solutions [10].

Table 5. Compositions of finishing mortars based on cement-limestone binder with superplasticizer J-1

\begin{tabular}{|c|c|c|c|c|c|}
\hline \multirow{2}{*}{ № } & \multirow{2}{*}{ Component name } & \multirow{2}{*}{$\begin{array}{c}\text { Unit of } \\
\text { measurement }\end{array}$} & \multicolumn{3}{|c|}{ Compositions of solutions } \\
\cline { 4 - 6 } & & № 1 & № 2 & № 3 \\
\hline 1 & Portland cement & $\%$ & 14.8 & 14.8 & 14.8 \\
\hline 2 & Construction lime & $\%$ & 4.8 & 4.8 & 4.8 \\
\hline 3 & Quartz sand & $\%$ & 65.2 & 65.1 & 65.0 \\
\hline 4 & Water & $\%$ & 15.0 & 15.0 & 15.0 \\
\hline 5 & Superplasticizer J-1 & $\%$ & 0.2 & 0.3 & 0.4 \\
\hline
\end{tabular}

Table 6. Composition of finishing composite mortars based on cement-limestone binder with GP-1 gel polymer

\begin{tabular}{|c|l|c|c|c|c|}
\hline \multirow{2}{*}{ № } & \multirow{2}{*}{ Component name } & \multirow{2}{*}{ Unit of measurement. } & \multicolumn{3}{|c|}{ Compositions of solutions. } \\
\cline { 3 - 6 } & & & № 1 & № 2 & № 3 \\
\hline 1 & Portland cement & $\%$ & 14.8 & 14.8 & 14.8 \\
\hline 2 & Construction lime & $\%$ & 4.8 & 4.8 & 4.8 \\
\hline 3 & Quartz sand & $\%$ & 65.2 & 65.1 & 65.0 \\
\hline 4 & Water & $\%$ & 15.0 & 15.0 & 15.0 \\
\hline 5 & GP-1 gel polymer & $\%$ & 0.2 & 0.3 & 0.4 \\
\hline
\end{tabular}

Table 7. Compositions of finishing composite mortars based on gypsum binder with GP-1 gel polymer.

\begin{tabular}{|c|c|c|c|c|c|}
\hline \multirow{2}{*}{$№$} & \multirow{2}{*}{ Component name } & \multirow{2}{*}{$\begin{array}{c}\text { Unit of } \\
\text { measurement. }\end{array}$} & \multicolumn{3}{|c|}{ Compositions of solutions. } \\
\cline { 4 - 6 } & & № 1 & № 2 & № 3 \\
\hline 1 & Construction lime & $\%$ & 35.6 & 35.6 & 35.6 \\
\hline 2 & Quartz sand & $\%$ & 36.1 & 36.0 & 35.9 \\
\hline 3 & Water & $\%$ & 28.0 & 28.0 & 28.0 \\
\hline 4 & GP-1 gel polymer & $\%$ & 0.3 & 0.4 & 0.5 \\
\hline
\end{tabular}

Table 8. Compositions of finishing composite mortars based on gypsum binder with superplasticizer J-1

\begin{tabular}{|c|c|c|c|c|c|}
\hline \multirow{2}{*}{ № } & \multirow{2}{*}{ Component name } & \multirow{2}{*}{$\begin{array}{c}\text { Unit of } \\
\text { measurement. }\end{array}$} & \multicolumn{3}{|c|}{ Compositions of solutions. } \\
\cline { 4 - 6 } & & № 1 & № 2 & № 3 \\
\hline 1 & Building plaster & $\%$ & 35.6 & 35.6 & 35.6 \\
\hline 2 & Quartz sand & $\%$ & 36.1 & 36.0 & 35.9 \\
\hline 3 & Water & $\%$ & 28.0 & 28.0 & 28.0 \\
\hline 4 & Superplasticizer J-1 & $\%$ & 0.3 & 0.4 & 0.5 \\
\hline
\end{tabular}

\section{Conclusions}

Seismic waves incident into any building structure are accompanied by spontaneous changes in the configuration of equilibrium stress fields in wall openings and plaster coatings. This increases the areas of reflected elastic waves in the zones of local stress localization. A spontaneous increase in microfractures is characteristic of weakened zones and zones with an increased stress field gradient, and a decrease is characteristic of 
monolithic (stable) areas of the material. The analysis of fractures for the conditions of materials on the territory of buildings showed that the vulnerability to micro-fracture of the body of materials is proportional to the seismic intensity and mainly changes due to seismic loading conditions, which is very important when optimizing macroseismic estimates.

As a result of the experimental work, the optimal compositions of finishing composite mortars with increased crack resistance and density were recommended.

\section{References}

1. Usmanova M.T., Ibragimov R.N., Dzhuraev A.D., Sadykov F.S., Shermatov M.Sh., Azizov G., Dzhuraev O., Dzhuraev O. To the study of the consequences of the Tashkent earthquake on August 22 2008, Problems of seismology in Uzbekistan Tashkent: IS of the Academy of Sciences of the Republic of Uzbekistan. № 6, pp.3-8, (2008)

2. Ziyaudinov F.F., Dzhuraev A., Dzhuraev N.M., Usmanova M.T., Nurmatov U.A., Gamidov L.A., Zakhidov T.K., Yusupdzhanova U.A. ., Dzhuraev O., Dzhuraev O. Cannes earthquake on July 20, 2011, Problems of seismology in Uzbekistan, № 9, pp.3-8, Tashkent, (2012)

3. Medvedev S.V. International scale of seismic intensity, Seismic zoning of the USSR. Science, pp. 151-162, (1968)

4. Rasskazovsky V.T. Fundamentals of physical methods for determining seismic effects, p. 160, Tashkent, (1973)

5. Maslennikov A.M. Assessment of constructive safety under dynamic impact, Collected reports of the bb-th scientific conf. SPbGASU, p. 55-60, (2009)

6. Sagdiev Kh.S., Teshaboev Z.R., Fasikhov V.G. Analysis of the impact of the Tashkent earthquake of August 22, 2008, Modern problems of mechanics.- Tashkent IMSS named after M.T. Urazbayev of the Academy of Sciences of the Republic of Uzbekistan, pp.466-472, (2009)

7. Ross H., Stahl F., Praxis-Handbuch Putz., Stoffe, Verarbeitung, Schadensvermeidung., 3. Auflage., Rudolf Muller Verlag., pp. 255, (2003)

8. Makhkamov S.M., Khamidov L.A. Microcracks in the body of materials under seismic loads, Modern technologies and innovations of the mining and metallurgical industry, Republican scientific-technical conference with international participation, pp. 455-456. Navoi. NGMK, (2012)

9. EN 998-1 "Specifications for mortars for masonry work. Part 1. Plaster mortar. - M: Building materials, p. 145, (2004)

10. Samigov N.A., Makhkamova S.M., Khamidov L.A., Turapov M.T., Earthquakeresistant building composites, pp. 124, Tashkent, (2014) 